\title{
An Evaluation of Automatic Text Summarization of News Articles: The Case of Three Online Arabic Text Summary Generators
}

\author{
Fahad M. Alliheibi ${ }^{1}$ \\ Department of Arabic Language, Faculty of Arts \\ King Abdulaziz University, Jeddah \\ Saudi Arabia
}

\author{
Abdulfattah Omar ${ }^{2}$ \\ Department of English, College of Science and Humanities \\ Prince Sattam Bin Abdulaziz University, Saudi Arabia \\ Department of English, Faculty of Arts \\ Port Said University, Egypt
}

\author{
Nasser Al-Horais ${ }^{3}$ \\ Department of Arabic Language and Arts \\ College of Arabic Language and Social Studies \\ Qassim University \\ Buraidah, Saudi Arabia
}

\begin{abstract}
Digital news platforms and online newspapers have multiplied at an unprecedented speed, making it difficult for users to read and follow all news articles on important, relevant topics. Numerous automatic text summarization systems have thus been developed to address the increasing needs of users around the world for summaries that reduce reading and processing time. Various automatic summarization systems have been developed and/or adapted in Arabic. The evaluation of automatic summarization performance is as important as the summarization process itself. Despite the importance of assessing summarization systems to identify potential limitations and improve their performance, very little has been done in this respect on systems in Arabic. Therefore, this study evaluated three text summarizers AlSummarizer, LAKHASLY, and RESOOMER using a corpus built of 40 news articles. Only articles written in Modern Standard Arabic (MSA) were selected as this is the formal and working language of Arab newspapers and news networks. Three expert examiners generated manual summaries and examined the linguistic consistency and relevance of the automatic summaries to the original news articles by comparing the automatic summaries to the manual (human) summaries. The scores for the three automatic summarizers were very similar and indicated that their performance was not satisfactory. In particular, the automatic summaries had serious problems with sentence relevance, which has negative implications for the reliability of such systems. The poor performance of Arabic summarizers can mainly be attributed to the unique morphological and syntactic characteristics of Arabic, which differ in many ways from English and other Western languages (the original language/s of automatic summarizers), and are critical in building sentence relevance and coherence in Arabic. Thus, summarization systems should be trained to identify discourse markers within the texts and use these in the generation of automatic summaries. This will have a positive impact on the quality and reliability of text summarization systems. Arabic summarization systems need to incorporate semantic approaches to improve performance and construct more coherent and meaningful summaries. This study was limited to news articles in MSA. However, the findings of the
\end{abstract}

study and their implications can be extended to other genres, including academic articles.

Keywords-AlSummarizer; Arabic; automatic summarization; discourse markers; extraction; LAKHASLY; news articles; RESOOMER; sentence relevance

\section{INTRODUCTION}

The recent unprecedented growth of digital news platforms and online newspapers has resulted in considerable changes in terms of news production and audience reception. Compared to traditional newspapers, digital news networks and online newspapers are extremely fast and easily accessible. Different reports indicate that online newspapers replaced traditional newspapers causing them to lose much of their audience [1]. That is why, almost all daily and weekly newspapers in the West and in the Arab world run their own websites and publish electronic editions [2-4]. Furthermore, news websites have now proliferated in an unprecedented manner, and without any of the traditional restrictions. There is no need for licenses, offices or even employees and correspondents. Anyone can create a news website in the same way used to create a personal website. This has the effect of producing fast and prolific news in an unprecedented manner.

The extensive number and popularity of online newspapers have changed the way people consume newspapers and magazines in many ways. According to Watson [5], by 2020, more than two-thirds of people in the United Kingdom were reading or downloading online news, newspapers, or magazines. In comparison to 2007, the number of online readers had tripled. As of February 2019, the Guardian and Mail Online were the second and third most popular websites in the UK, respectively, as shown in Fig. 1. 


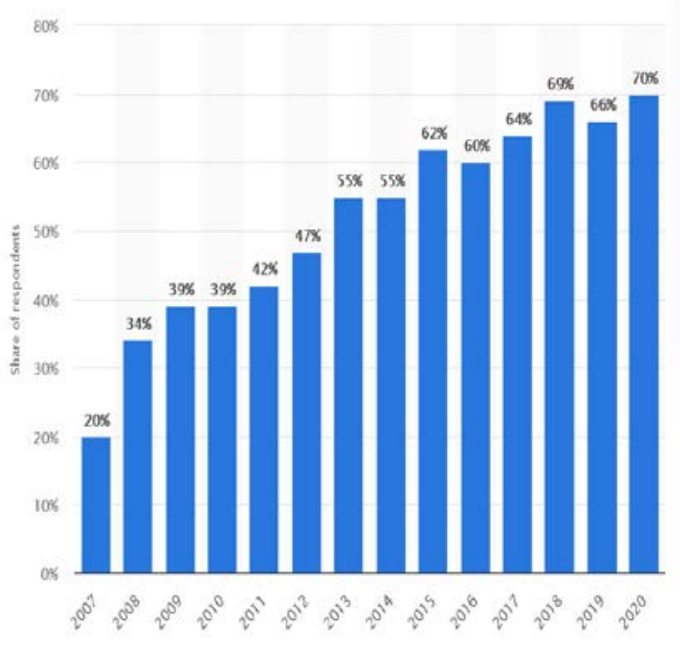

Fig. 1. Share of Individuals Reading or Downloading Online News, Newspapers or Magazines in Great Britain from 2007 to 2020 (Statista.com).

In the same study, Thurman [6] asserts that over recent years online newspapers and news websites have been gaining massive popularity and increasing in an unprecedented manner. In the face of these developments, it is impossible for a normal audience to follow all that is written on important and relevant topics. It is a challenging task for individuals to read this huge content in a limited time span, as the news changes daily if not hourly.

In response, numerous automatic summarization systems have been developed over recent years to generate meaningful summaries that can reduce reading and processing times. Researchers have developed summarization tools and methods that automatically summarize the content of news articles in effective ways. It is even argued that summarization has become an integral part of everyday life [7]. This can be seen in the rapid developments of numerous applications and websites including Summarize Bot, Resoomer, SMMRY, Inshorts, and Text Summarization API (Rapid API) that provide summarization services to news articles to millions of users around the world.

Despite the availability of text summarizers in different languages including Chinese, English, French, and Spanish that provide good summarization services for millions of global users, automatic summarization in Arabic is still very limited. This can be attributed to the unique linguistic system of Arabic where multilingual text summarizers cannot be used with Arabic texts. It is also true that the morphological and syntactic properties of Arabic still pose serious challenges for different Natural Language Processing (NLP) applications, including information retrieval, localization, machine translation, and automatic text summarization [8, 9].

Another reason for this limitation is the lack of evaluation studies of automatic Arabic text summarization. Evaluation is an integral part in the automatic summarization process [1016]. According to $\mathrm{Al}$ Qassem, et al. [17], the evaluation process is one of the main challenges that have adverse impacts on the availability and reliability of automatic Arabic text summarization systems. This can be attributed to the lack of gold standard summaries for Arabic. They add that automatic evaluation of Arabic summarization is more complicated due to the lack of Arabic benchmark corpora, lexica, and machine-readable dictionaries.

To address this limitation, an evaluation of three text summarizers AlSummarizer, LAKHASLY, and RESOOMER is carried out hereunder. A corpus of 40 news articles was built. The articles were randomly selected from the most popular and digital news networks and online newspapers in the Arab world. It was, however, considered that the selected news articles cover different themes and subjects including politics, business, sports, and entertainment. Only articles written in Modern Standard Arabic were selected. The rationale being that MSA is still the formal and working language of the Arab newspapers and news networks.

The remainder of this article is organized as follows. Section 2 is a brief survey of automatic summarization literature in general and automatic Arabic text summarization systems in particular. Section 3 defines the research methods and procedures. In this part, the selected summarizers and articles are defined. Procedures of carrying out the study are also defined and established. Section 4 reports the results. It evaluates the performance of the selected summarizers regarding the news articles. Section 5 concludes the study.

\section{Previous Work}

Previously, text summarizations were carried out using non-computational methods, using philological methods where experts and professionals produced their summaries based on their own evaluation of the most important concepts in the texts under investigation. With the development of digital technologies, computational approaches have been integrated into text summarization for generating automatic summaries of different text genres. It can be obviously seen that the recent years have witnessed an increasing rate in the development of automatic text summarizers. These have been essentially developed to address the increasing needs of users all over the world. Gambhir and Gupta [18] assert that it has now become impossible for traditional or non-computational classification methods to deal with the large amounts of data available today. They indicate that conventional or noncomputational summarization methods are no longer effective or reliable to deal with the prolific size of digital texts and archives available on the internet. According to Cheng and Lapata [19], the need to access and digest large amounts of textual data has provided strong impetus to develop automatic summarization systems, aiming to create shorter versions of one or more documents, whilst preserving their information content. Much effort in automatic summarization has been devoted to sentence extraction, where a summary is created by identifying and subsequently concatenating the most salient text units in a document.

Soni, et al. [20] agree that due to massive rate of rising data at a on the Internet, automatic text summarization tools have a powerful effect on today's world. The entire material is very difficult for a person to describe and ingest. It is a very difficult task to manually convert or summarize, hence, automation is required. Using artificial intelligence methods, automatic text summarization can be accomplished. 
Nenkova and McKeown [21] add that objectivity and consistency have always been main considerations in automatic summarizations. The argument is that automatic summarization is imperative for addressing the inconsistencies and lack of objectivity that were associated with conventional or non-computational methods of text summarization.

The first attempt of computer-based text summarization is attributed to Hans Peter Luhn in 1958 [22-25]. In his article 'The Automatic Creation of Literature Abstracts', Luhn [26] proposed an algorithm to facilitate quick and accurate identification of the topic of published papers in a way that saves prospective readers time and effort in finding useful information in a given article or report. The underlying principle of Luhn's approach was that the salient points of an author's argument can be identified through the statistical analysis of the most frequent words and phrases occurring in texts. The hypothesis was that authors generally use important words more frequently throughout a paper and this can be conveniently used as a predictor for selecting the sentences with more repetition of the keywords and extracting them to generate an automatic summary [27-29].

Despite the development of different approaches to automatic text summarization, extractive methods remain the most popular summarization methods. In such methods, automatic summarizers are trained to identify the most important phrases and sentences, usually using statistical methods, and generate automatic summaries based on the extraction process of these sentences and phrases. Extractivebased summarization approaches are based on identifying and selecting only the most important phrases and sentences in texts under consideration. To generate an automatic summary, automatic summarizers then incorporate all the important phrases and sentences. In this case, therefore, every line and word of the summary actually belongs to the original summarized text [30].

In Arabic, over recent years, a very limited number of automatic text summarization systems have been developed, compared to other languages including English, Spanish, and Chinese [16, 17, 31]. Al-Saleh and Menai [10] comment that despite the long history of text summarization, studies of the Arabic language in this area have only recently emerged, and they have been negatively influenced by the lack of Arabic gold standard summaries.

The literature indicates that automatic text summarization systems have been largely based on extractive methods. These extractive summarization systems are mainly based on numerical and statistical measures [32-36]. The main hypothesis in these approaches is the ability of training the machine to identify the most important sentences and phrases for building the summaries. This is usually carried out through using different statistical measures including Principal Components Analysis (PCA) and Term-Frequency Adverse Document-Frequency (TD-IDF). To simplify, these weighting methods are used as indicators for retaining only the important information within texts and discarding information of secondary or minor importance. Successful implementation of these mechanisms is thus a critical factor for the success of summarization systems [37].
Weighting methods are usually combined with other methods that support the identification of the most important sentences, clauses, and phrases in the texts. One popular method is the position or location of sentences. The premise is that the location of a sentence in a document is related to the amount of information it contains. Other techniques involve grouping and summarizing related texts in a process known as multi-document summarization.

The argument is that the majority of automatic Arabic summarization systems are based on statistical methods. One limitation with these techniques is that automatic summaries are based only on those sentences with the highest scores based on statistical measures and techniques. In response, symbolic approaches have been adopted [38-41]. Unlike the numerical and statistical approaches, symbolic-based extractive summarization systems are based solely on linguistic information and indicators for identifying the most important sentences and expressions within texts. The premise of such approaches is that summaries should be built on a rhetorical structure that considers the rhetorical relations within texts. Work on symbolic-based extractive summarization systems is still very limited.

Over recent years, work on/with automatic Arabic summarization systems has reflected on the development of online summarizers that provide summarization services for users in an easy and accessible way. These summarizers are based on the developments in automatic Arabic summarization research and industry. One major problem, however, is the lack of evaluation studies that can determine the readability and reliability of these summarizers. This study addresses this gap in the literature through an evaluation of three Arabic summarizers, namely AlSummarizer, LAKHASLY, and RESOOMER.

\section{Methods AND Results}

This study is based on a corpus of 40 newspaper articles. The articles were selected from nine newspapers issued published in different Arab countries, as shown in Table 1.

The selected articles and opinions represent different topics including politics, business, and sports as shown in Table 2.

TABLE I. THE SELECTED NEWSPAPERS

\begin{tabular}{|c|c|c|}
\hline \multicolumn{3}{|c|}{ Selected newspapers } \\
\hline Newspaper Title & Country & Number of articles \\
\hline Al-Ahram & Egypt & 8 \\
\hline Al-Bayan & Emirates & 4 \\
\hline Al-Itihad & Emirates & 3 \\
\hline Alrai & Jordan & 3 \\
\hline Al-Watan & Kuwait & 4 \\
\hline Annahar & Lebanon & 4 \\
\hline Assabah & Morocco & 4 \\
\hline Al-Jazeera & Saudi Arabia & 5 \\
\hline Asharq Al-Awsat & Saudi Arabia & 5 \\
\hline
\end{tabular}


TABLE II. TOPICS OF THE SELECTED ARTICLES

\begin{tabular}{|l|l|}
\hline Articles topics & \multicolumn{2}{|l|}{ Number of articles } \\
\hline Category & 8 \\
\hline Politics & 8 \\
\hline Business & 8 \\
\hline Sports & 8 \\
\hline Entertainment/Culture/ Family (ETF) & 8 \\
\hline Science/Technology & \\
\hline
\end{tabular}

For convenience, the selected articles were coded 01-40, as shown in Table 3. The full information pertaining to the selected articles, including transliteration and English translations of the headlines of the selected articles is given in Appendix No. 1.

TABLE III. NEWSPAPER ARTICLES AND CODES

\begin{tabular}{|c|c|c|c|}
\hline \multicolumn{4}{|l|}{ Newspaper articles and codes } \\
\hline Title & Code & Category & Newspaper \\
\hline تحرير الأسعار .... وقود الحر ائق & 01 & Business & Assabah \\
\hline عتزة صدقى: صناعة السباحة على مستوى العالم & 02 & Business & Al-Ahram \\
\hline تسهيلات جمركية للسبيارات الكهر بائية المستعملة & 03 & Business & Al-Ahram \\
\hline تدهور تاريخي للبرة السورية أماح الدو لار & 04 & Business & Al-Watan \\
\hline 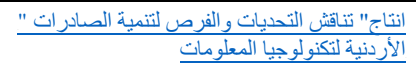 & 05 & Business & Alrai \\
\hline 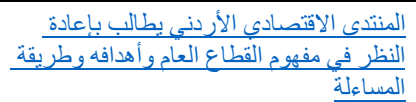 & 06 & Business & Alrai \\
\hline أير أسبا: نعمل على إطلاق خدمة الناكسي الطائر & 07 & Business & Al-Itihad \\
\hline تجاري لسيدات خلال النودية: منح 100 ألف سجل & 08 & Business & Al-Bayan \\
\hline إدانة ساركوزي بتهم الفساد & 09 & Politics & Assabah \\
\hline "لإالنقاء الدولى إعداد يدعو الدكوماتهات للنظر بعين الاعتبار & 10 & Politics & Al-Ahram \\
\hline 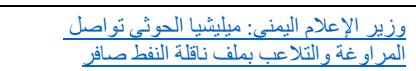 & 11 & Politics & Al-Ahram \\
\hline زئشرة بكابا الفاتيكان للعراق استدعاء لقيم العيش & 12 & Politics & Al-Ahram \\
\hline المقلق سعوديني من تنامي وتيرة خطاب الكر اهية ضد & 13 & Politics & Al-Jazeera \\
\hline إرهابهير تطالب مجلس الأمن بمحاسبة الحوثيين على & 14 & Politics & $\begin{array}{l}\text { Asharq Al- } \\
\text { Awsat }\end{array}$ \\
\hline إرادة الثعب و المر اهقة السباسية & 15 & Politics & Al-Watan \\
\hline آلآنتاف الجز ائريين بتظظاهرون في الاسبو ع الثانى من & 16 & Politics & Alrai \\
\hline كاف" ثطلق عصبة الأبطال النسوية"، & 17 & Sports & Assabah \\
\hline كلوب: الهزيمة أمام تشيلسى ضربة قوبة & 18 & Sports & $\begin{array}{l}\text { Asharq Al- } \\
\text { Awsat }\end{array}$ \\
\hline الإفلاس يضرب 16 ناديأ في الدوري الصيني & 19 & Sports & Al-Jazeera \\
\hline الأسطورة بوفون بكشف مو عد اعتز اله & 20 & Sports & Al-Watan \\
\hline "ادربي" مانشستر في الو اجهة.... وليفربول لاستعادة. & 21 & Sports & Annahar \\
\hline الكرة المصرية... مو اهب 》ارتلفها الهوى & 22 & Sports & Al-Bayan \\
\hline 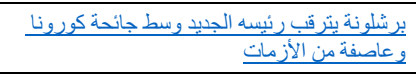 & 23 & Sports & Al-Bayan \\
\hline إبر اهيموفيتش.. .العودة وشيكة، إلى منتخب السويد & 24 & Sports & Al-Itihad \\
\hline
\end{tabular}

\begin{tabular}{|c|c|c|c|}
\hline في در التغلب طبية: توفير الثئقة و الدعم للمر اهقين بساعدهم & 25 & ETF & Al-Ahram \\
\hline 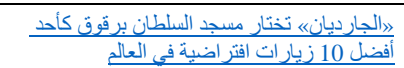 & 26 & ETF & Al-Ahram \\
\hline أفلام مخرجين صنعت السينما & 27 & ETF & $\begin{array}{l}\text { Asharq Al- } \\
\text { Awsat }\end{array}$ \\
\hline سنوات النينمي & 28 & ETF & $\begin{array}{l}\text { Asharq Al- } \\
\text { Awsat }\end{array}$ \\
\hline السينما بعيون أفلاطون & 29 & ETF & Al-Jazeera \\
\hline يتحول الصحف الدعة الورقية إلىى إلكترونية بيسير وتحتاج & 30 & ETF & Al-Jazeera \\
\hline وودثائقي جديد يكثف الوجه القبيح للمخرج الأمريكي & 31 & ETF & Al-Watan \\
\hline الحب المتبادل ينمي ذكاء الأطفال & 32 & ETF & Assabah \\
\hline ضولئية فقطيُون عن آثار حياة على بعد 26 سنة & 33 & $\mathrm{~S} \& \mathrm{~T}$ & Al-Itihad \\
\hline 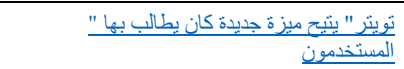 & 34 & $\mathrm{~S} \& \mathrm{~T}$ & Al-Bayan \\
\hline والويب قربيباً تقن المكالمات الصوتية و المرئية لتطبيق & 35 & $S \& T$ & Annahar \\
\hline "الثيبية بفيديو تات Fast Laughs تنفليكس تطلق & 36 & $S \& T$ & Annahar \\
\hline "بايت دانس" تطور تطبيقًا شبيهاً بـ "كلوب هاوس" & 37 & S \& T & Annahar \\
\hline أداة ذكية تدمج بالهاتف لقياس الحر ارة & 38 & $S \& T$ & Al-Jazeera \\
\hline هياكل روبوتية خارجية تدعم قوة العمل البشرية & 39 & $\mathrm{~S} \& \mathrm{~T}$ & $\begin{array}{l}\text { Asharq Al- } \\
\text { Awsat }\end{array}$ \\
\hline القلب العالية يكيث عن سبب دقات & 40 & $\mathrm{~S} \& \mathrm{~T}$ & Al-Ahram \\
\hline
\end{tabular}

The selected articles were summarized using three Arabic summarizers: AlSummarizer, LAKHASLY, and RESOOMER. These are currently the most popular Arabic summarizers. All three summarizers are based on extractive summarization methods. AlSummarizer is multilingual software that provides summarization solutions in different languages including Arabic, Dutch, English, Farsi, and Turkish. LAKHASLY is an Online Summarization tool. It provides automatic summaries for Arabic and English texts. It is widely used all over the world for users interested in Arabic summaries. Finally, RESOOMER is online summarizers which provide summarization services in different languages including Arabic, English, French, German, Italian, Polish, and Spanish.

For evaluating the performance of the selected summarizers, manual (human) evaluation methods were used. Three examiners were selected to generate manual summaries and to examine the linguistic consistency and relevance of the automatic summaries to the original news articles.

\section{ANALYSIS AND DISCUSSIONS}

To evaluate the performance of the three selected Arabic summarizers, the automatic summaries were compared to the manual (human) summaries produced by the experts who participated in the study. Results are shown in Table 4, Table 5, and Table 6.

Comparisons to the manual summaries indicate that the scores of the three summarizers are very similar. The scores also indicate that the performance of the three summarizers is not satisfactory. This has negative impacts on the reliability of these summarizers. Another problem with the three summarizers is the lack of sentence relevance and coherence. 
This can be seen in the following example taken from LAKHASLY. There is a problem with the sentence relevance. Sentences are not well connected to one another, which has adverse impacts on the readability and understanding what the original text about, as shown in Box 1.

TABLE IV. SENTENCE OVERLAP IN THE AUtOMATIC SUMMARIES GENERATED BY ALSUMMARIZER

\begin{tabular}{|l|l|l|lr|}
\hline $\begin{array}{l}\text { Document } \\
\text { Code }\end{array}$ & $\begin{array}{l}\text { Percentage } \\
\text { Overlap }\end{array}$ & of & Document Code & $\begin{array}{l}\text { Percentage } \\
\text { Overlap }\end{array}$ \\
\hline 01 & 33 & 21 & 47 \\
\hline 02 & 37 & 22 & 34 \\
\hline 03 & 36 & 23 & 36 \\
\hline 04 & 42 & 24 & 49 \\
\hline 05 & 33 & 25 & 35 \\
\hline 06 & 38 & 26 & 48 \\
\hline 07 & 49 & 27 & 36 \\
\hline 08 & 51 & 28 & 45 \\
\hline 09 & 47 & 29 & 52 \\
\hline 10 & 39 & 30 & 48 \\
\hline 11 & 42 & 31 & 36 \\
\hline 12 & 41 & 32 & 31 \\
\hline 13 & 35 & 33 & 33 \\
\hline 14 & 42 & 34 & 37 \\
\hline 15 & 44 & 35 & 43 \\
\hline 16 & 49 & 36 & 45 \\
\hline 17 & 37 & 37 & 37 \\
\hline 18 & 38 & 38 & 36 \\
\hline 19 & 33 & 39 & 44 \\
\hline 20 & 43 & 40 & 47 \\
\hline & & & \\
\hline
\end{tabular}

TABLE V. SENTENCE OVERLAP IN THE AUTOMATIC SUMMARIES GENERATED BY LAKHASLY

\begin{tabular}{|c|c|c|c|}
\hline Document Code & $\begin{array}{ll}\begin{array}{l}\text { Percentage } \\
\text { Overlap }\end{array} & \text { of } \\
\end{array}$ & Document Code & $\begin{array}{ll}\text { Percentage } & \text { o } \\
\text { Overlap } & \end{array}$ \\
\hline 01 & 37 & 21 & 4 \\
\hline 02 & 36 & 22 & 37 \\
\hline 03 & 33 & 23 & 3 \\
\hline 04 & 37 & 24 & 48 \\
\hline 05 & 36 & 25 & 3 \\
\hline 06 & 48 & 26 & 3 \\
\hline 07 & 37 & 27 & 4 \\
\hline 08 & 40 & 28 & 4 \\
\hline 09 & 41 & 29 & 3 \\
\hline 10 & 35 & 30 & 3 \\
\hline 11 & 41 & 31 & 4 \\
\hline 12 & 51 & 32 & 38 \\
\hline 13 & 47 & 33 & 3 \\
\hline 14 & 39 & 34 & 4 \\
\hline 15 & 44 & 35 & 42 \\
\hline 16 & 41 & 36 & 4 \\
\hline 17 & 53 & 37 & 38 \\
\hline 18 & 33 & 38 & 4 \\
\hline 19 & 37 & 39 & 40 \\
\hline 20 & 36 & 40 & 52 \\
\hline
\end{tabular}

TABLE VI. SENTENCE OVERLAP IN THE AUTOMATIC SUMMARIES GENERATED BY RESOOMER

\begin{tabular}{|l|l|l|r|}
\hline $\begin{array}{l}\text { Document } \\
\text { Code }\end{array}$ & $\begin{array}{l}\text { Percentage } \\
\text { Overlap }\end{array}$ & $\begin{array}{l}\text { Document } \\
\text { Code }\end{array}$ & $\begin{array}{l}\text { Percentage } \\
\text { Overlap }\end{array}$ \\
\hline 01 & 36 & 21 & 41 \\
\hline 02 & 31 & 22 & 53 \\
\hline 03 & 33 & 23 & 33 \\
\hline 04 & 37 & 24 & 37 \\
\hline 05 & 43 & 25 & 36 \\
\hline 06 & 45 & 26 & 38 \\
\hline 07 & 37 & 27 & 49 \\
\hline 08 & 36 & 28 & 51 \\
\hline 09 & 44 & 29 & 47 \\
\hline 10 & 47 & 30 & 39 \\
\hline 11 & 37 & 31 & 42 \\
\hline 12 & 36 & 32 & 41 \\
\hline 13 & 33 & 33 & 35 \\
\hline 14 & 37 & 34 & 42 \\
\hline 15 & 36 & 35 & 44 \\
\hline 16 & 48 & 36 & 49 \\
\hline 17 & 37 & 37 & 37 \\
\hline 18 & 40 & 38 & 38 \\
\hline 19 & 41 & 39 & 33 \\
\hline 20 & 35 & 40 & 43 \\
\hline
\end{tabular}

TABLE VII. BOX No. 1. AN AutOMATIC SUMmary GENERATED By LAKHASLY

Original Text

أعربت المملكة أمس عن القلق الثديد من تنامي وتيرة خطاب الكر اهية و التعصب ضد المبد المسلمين حول

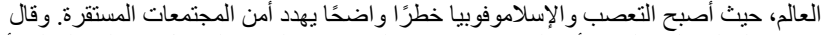

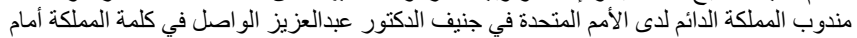

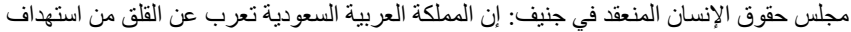

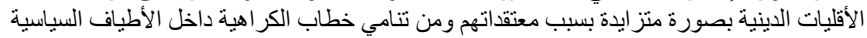

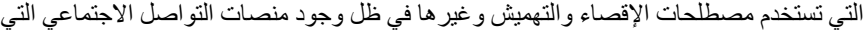

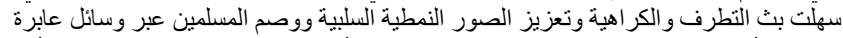

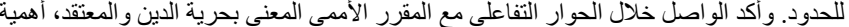

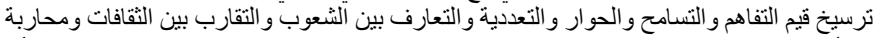

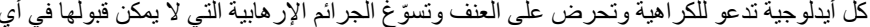

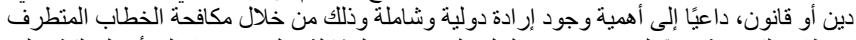

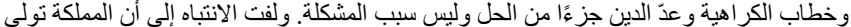

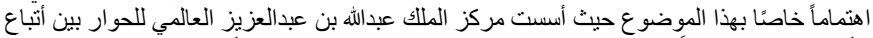

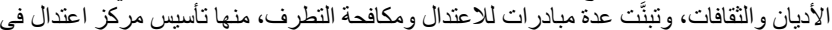

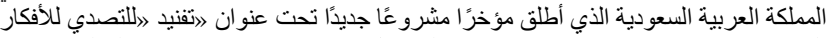

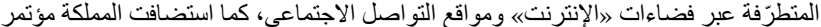

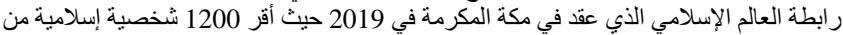

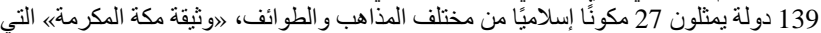

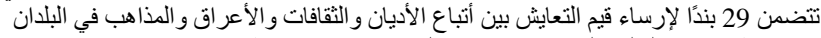
الإسلامية وتحقيق السلم و التوئام بين مكونات المجنمع الإنساء لإنساني كافة.

Summary

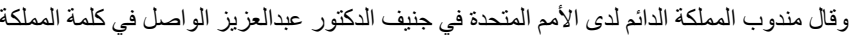

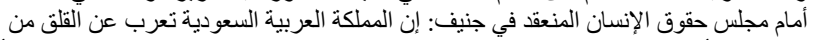

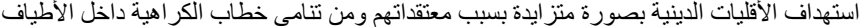

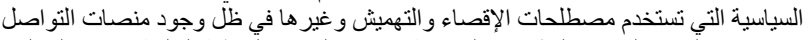

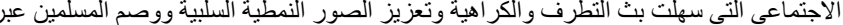

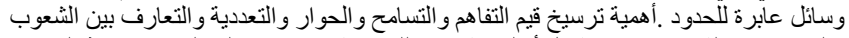

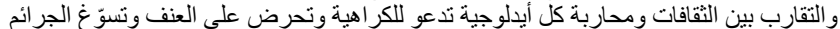

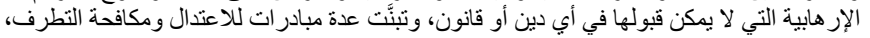

Omar [42] explains that if sentences and clauses in the automatic summaries are not connected, the overall argumentative structure of the text is not supported and the 
thematic significance of the original texts is lost. He adds that in many cases automatic summaries generated in this fashion are misleading for readers and users. Alami, et al. [43] agree that one main reason for the low performance of text summarizers in Arabic is that sentences in the extracted or generated summaries are not relevant; therefore, the main point of the original texts is not clear. The lack of sentence relevance thus has negative impacts on the user's ability to grasp the meaning of original texts. In such a case, automatic summaries do not provide the users with concise and relevant information that helps them determine and assess the importance of texts without having to read all of the texts.

The lack of sentence relevance and coherence in automatic summarization in Arabic can be attributed to the multilingual nature of automatic text summarizers. Many of the summarizers are usually offered in different languages without considering language- specificity. It is almost agreed upon, that the unique linguistic properties of Arabic are always associated with the low performance in different natural language processing (NLP) applications including automatic summarization $[10,17,44-46]$. To put it into context, the morpho-syntactic system of Arabic is different in many ways from English and other Western languages (the original language/s of automatic summarizers). The morphological and syntactic properties of Arabic are indispensable in building sentence relevance and coherence in Arabic. According to Al Qassem, et al. [17], the main challenge in Arabic text summarization is in the complexity of the Arabic language itself: 1) the meaning of a text is highly dependent on the context; 2) there are more inherent variations within Arabic than any other language; 3) the diacritics are usually absent in the texts of news articles and any online content.

To improve the sentence relevance in the automatic summarization of news articles in Arabic, this study proposes that summarization systems should be trained to identify the discourse markers within the texts and furthermore to use these discourse markers in the generation of automatic summaries. The hypothesis is that discourse markers can be gainfully used to create cohesive texts with sentences that are linked together and relevant to one another. In other words, discourse markers can be used to build cohesive and coherent texts through interrelated sentences which will have positive impacts on the quality and reliability of text summarization systems. Arabic summarization systems need to integrate semantic-based methods for improving the quality of summarization performance and generating more coherent and meaningful summaries.

\section{CONCLUSION}

Digital news platforms and online newspapers have multiplied today at an unprecedented speed, making it difficult for users to read and follow all news articles on important relevant topics. Numerous automatic text summarization systems have thus been developed to address the increasing needs of users around the world to access summaries that reduce reading and processing time. In Arabic, different automatic summarization systems have been developed and/or adapted in order to address the increasing need for automatic
Arabic summaries. Evaluation of automatic summarization performance is as important as automatic summarization itself.

Despite the importance of the evaluation and assessment of automatic summarization systems for identifying the limitations and for improving the summarization performance, very little has been done on the evaluation systems of automatic text summarization in Arabic. Therefore, an evaluation of three text summarizers AlSummarizer, LAKHASLY, and RESOOMER was carried out. A corpus of forty news articles was built. Only articles written in Modern Standard Arabic (MSA) were selected. The rationale being that MSA is still the formal and working language of Arab newspapers and news networks. For evaluating the performance of the selected summarizers, manual (human) evaluation methods were used. Three examiners were selected to generate manual summaries and to examine the linguistic consistency and relevance of the automatic summaries to the original news articles. To evaluate the performance of the three selected Arabic summarizers, the automatic summaries were compared to the manual (human) summaries produced by the experts who participated in the study. Results indicated that the scores of the three summarizers were very similar. The scores also indicate that the performance of the three summarizers is not satisfactory. Furthermore, the automatic summaries have a serious problem with sentence relevance that has adverse impacts on the reliability of such systems.

It can be concluded that the poor performance of Arabic summarizers can be mainly attributed to the unique morphological and syntactic characteristics of Arabic. The morphological-syntactic system of Arabic is different in many ways from English and other Western languages (the original language/s of automatic summarizers). The morphological and syntactic properties of Arabic are indispensable in building sentence relevance and coherence in Arabic. Thus, this study proposes that summarization systems should be trained to identify the discourse markers within the texts and furthermore to use these discourse markers in the generation of automatic summaries. This will have positive impacts on the quality and reliability of text summarization systems. Arabic summarization systems need to incorporate semantic approaches for improving the quality of summarization performance and building more coherent and meaningful summaries.

This study was limited to the news articles in MSA. However, the findings of the study and their implications can be extended to other genres including academic articles. Further research, however, is recommended to address the performance of automatic Arabic text summarization in social media language and colloquial dialects in Arabic.

\section{ACKNOWLEDGMENT}

The corresponding author would like to acknowledge the support provided by the Deanship of Scientific Research (DSR) at King Abdulaziz University, Jeddah, Saudi Arabia.

REFERENCES

[1] E. Siapera and A. Veglis, The Handbook of Global Online Journalism. New York: Wiley, 2012.

[2] W. A. Rugh, Arab mass media: Newspapers, radio, and television in Arab politics. Greenwood publishing group, 2004. 
[3] B. Garrison, "Online newspapers," Online news and the public, pp. 3-46, 2005.

[4] M. Gasher and S. Gabriele, "Increasing circulation? a comparative newsflow study of the Montreal Gazette's hard-copy and on-line editions," Journalism Studies, vol. 5, no. 3, pp. 311-323, 2004.

[5] A. Watson. Online news, newspaper and magazine consumption in Great Britain 2007-2020 [Online]. Available: https://www.statista.com/ statistics/286210/online-news-newspapers-and-magazine-consumptionin-great-britain/

[6] N. Thurman, "Newspaper consumption in the digital age: Measuring multi-channel audience attention and brand popularity," Digital Journalism, vol. 2, no. 2, pp. 156-178, 2014.

[7] U. Hahn and I. Mani, "The Challenges of Automatic Summarization," Computer, vol. 33, no. 11, pp. 29-36, 2000.

[8] A. Omar, "An Evaluation of the Localization Quality of the Arabic Versions of Learning Management Systems," International Journal of Advanced Computer Science and Applications, vol. 12, no. 2, pp. 443449, 2021.

[9] A. Omar, "Ambiguity Resolution in Arabic Localization: The Case of Learning Management Systems," Applied Linguistics Research Journal, vol. 5, no. 1, pp. 1-6, 2021.

[10] A. B. Al-Saleh and M. E. B. Menai, "Automatic Arabic text summarization: a survey," Artificial Intelligence Review, vol. 45, no. 2, pp. 203-234, 2016.

[11] F. Kiyoumarsi, "Evaluation of Automatic Text Summarizations Based On Human Summaries," Procedia - Social and Behavioral Sciences, vol. 192, pp. 83-91, 2015.

[12] M. Lapata and R. Barzilay, "Automatic Evaluation of Text Coherence: Models and Representations," Proceedings of the 19th International Joint Conference on Artificial Intelligence, pp. 1085-1090, 2005.

[13] L. D. Robert, W. D. Kevin, and A. M. Laura, "A comparison of rankings produced by summarization evaluation measures," presented at the Proceedings of the 2000 NAACL-ANLP Workshop on Automatic Summarization, Seattle, Washington, 2000.

[14] L. Scanlon, S. Zhang, X. Zhang, and M. Sanderson, "Evaluation of Cross Domain Text Summarization," in Proceedings of the 43rd International ACM SIGIR Conference on Research and Development in Information Retrieval, 2020, pp. 1853-1856.

[15] J. Steinberger and K. Jezek, "Evaluation Measures for Text Summarization," Computing and Informatics, vol. 28, no. 2, pp. 251275, 2009.

[16] L. Belguith, M. Ellouze, M. Maaloul, M. Jaoua, F. Jaoua, and P. Blache, "Automatic summarization," in Natural language processing of semitic languages, theory and applications of natural language processing, I. Zitouni, Ed. Berlin: Springer, 2014, pp. 371-408.

[17] L. M. Al Qassem, D. Wang, Z. Al Mahmoud, H. Barada, A. Al-Rubaie, and N. I. Almoosa, "Automatic Arabic summarization: a survey of methodologies and systems," Procedia Computer Science, vol. 117, pp. 10-18, 2017.

[18] M. Gambhir and V. Gupta, "Recent automatic text summarization techniques: a survey," Artificial Intelligence Review, vol. 47, no. 1, pp. 1-66, 2017.

[19] J. Cheng and M. Lapata, "Neural summarization by extracting sentences and words," arXiv preprint arXiv:1603.07252, 2016.

[20] V. Soni, L. Kumar, A. K. Singh, and M. Kumar, "Text Summarization: An Extractive Approach," in Soft Computing: Theories and Applications. Advances in Intelligent Systems and Computing, vol. 1154, M. Pant, K. Sharma, R. Arya, B. Sahana, and H. Zolfagharinia, Eds. Singapore: Springer, 2020.

[21] A. Nenkova and K. McKeown, Automatic summarization. Now Publishers Inc, 2011.

[22] I. Mani, Automatic Summarization. Amsterdam: John Benjamins Publishing, 2001.

[23] A. Fiori, Trends and Applications of Text Summarization Techniques. IGI Global, 2019.

[24] Torres-Moreno and Juan-Manuel, Automatic text summarization. Hoboken, NJ: John Wiley \& Sons, 2014.
[25] R. C. Balabantaray, D. Sahoo, B. Sahoo, and M. Swain, "Text summarization using term weights," International Journal of Computer Applications, vol. 38, no. 1, pp. 10-14, 2012.

[26] H. P. Luhn, "The Automatic Creation of Literature Abstracts," IBM Journal of Research and Development, no. April, pp. 159-165, 1958.

[27] A. Fiori, Innovative Document Summarization Techniques: Revolutionizing Knowledge Understanding: Revolutionizing Knowledge Understanding. Hershey, Pennsylvania: IGI Global, 2014.

[28] J. Madhuri and R. G. Kumar, "Extractive Text Summarization Using Sentence Ranking," 2019 International Conference on Data Science and Communication (IconDSC), pp. 1-3, 2019.

[29] Y. K. Meena and D. Gopalani, "Analysis of sentence scoring methods for extractive automatic text summarization," Proceedings of the 2014 international conference on information and communication technology for competitive strategies, pp. 1-6, 2014.

[30] D. D. A. Bui, G. Del Fiol, J. F. Hurdle, and S. Jonnalagadda, "Extractive text summarization system to aid data extraction from full text in systematic review development," Journal of Biomedical Informatics, vol. 64, pp. 265-272, 2016/12/01/ 2016.

[31] M. Boudabous, M. Maaloul, and L. Belguith, "Digital learning for summarizing arabic documents," in Advances in natural language processing, lecture notes in computer science, vol. 6233, H. Loftsson, E. Rgnvaldsson, and S. Helgadttir, Eds. Berlin: Springer, 2010, pp. 79-84.

[32] F. Douzidia and G. Lapalme, "Lakhas, an arabic summarization system," DUC 2004, pp. 128-135, 2004.

[33] F. El-Ghannam and T. El-Shishtawy, "Multi-topic multi-document summarizer," Int J Comput Sci Inf Technol, vol. 5, no. 6, pp. 77-90, 2013.

[34] M. El-Haj, U. Kruschwitz, and C. Fox, "Exploring clustering for multidocument arabic summarisation," in Information retrieval technology, vol. 7097, M. Salem, K. Shaalan, F. Oroumchian, A. Shakery, and H. Khelalfa, Eds. (lecture notes in computer science, Berlin: Springer, 2011, pp. 550-561.

[35] N. El-Fishawy, A. Hamouda, G. Attiya, and M. Atef, "Arabic summarization in twitter social network," Ain Shams Engineering Journal, vol. 5, no. 2, pp. 411-420, 2013.

[36] R. Belkebir and A. Guessoum, "A supervised approach to arabic text summarization using adaboost," in New contributions in information systems and technologies, advances in intelligent systems and computing, vol. 353, A. Rocha, A. Correia, S. Costanzo, and L. Reis, Eds., 2015, pp. 227-236.

[37] K. Nandhini and S. R. Balasundaram, "Improving readability through extractive summarization for learners with reading difficulties," Egyptian Informatics Journal, vol. 14, no. 3, pp. 195-204, 2013/11/01/ 2013.

[38] W. Al-Sanie, "Towards an infrastructure for arabic text summarization using rhetorical structure theory," Master's thesis, King Saud University, Riyadh, 2005.

[39] F. AL-Khawaldeh and V. Samawi, "Lexical cohesion and entailment based segmentation for arabic text summarization (lceas)," World Comput Sci Inf Technol J, vol. 5, no. 3, pp. 51-60, 2015.

[40] H. Fejer and N. Omar, "Automatic arabic text summarization using clustering and keyphrase extraction," 2014 International Conference on information technology and multimedia (ICIMU), pp. 293-298, 2014.

[41] A. Ibrahim and T. Elghazaly, "Improve the automatic summarization of arabic text depending on rhetorical structure theory," 12th Mexican International Conference on Artificial Intelligence (MICAI), pp. 223227, 2013.

[42] A. Omar, "Addressing the Problem of Coherence in Automatic Text Summarization: A Latent Semantic Analysis Approach," International Journal of English Linguistics, vol. 7, no. 4, pp. 33-44, 2017.

[43] N. Alami, N. En-nahnahi, S. A. Ouatik, and M. Meknassi, "Using unsupervised deep learning for automatic summarization of Arabic documents," Arabian Journal for Science and Engineering, vol. 43, no. 12, pp. 7803-7815, 2018.

[44] A. Omar and W. I. Hamouda, "The Effectiveness of Stemming in the Stylometric Authorship Attribution in Arabic," International Journal of 
Advanced Computer Science and Applications, vol. 11, no. 1, pp. 116121, 2020.

[45] A. Omar and M. Aldawsari, "Lexical Ambiguity in Arabic Information Retrieval: The Case of Six Web-Based Search Engines," International Journal of English Linguistics, vol. 10, no. 3, pp. 219-228, 2020.

[46] A. Farghaly and K. Shaalan, "Arabic natural language processing: challenges and solutions " ACM Transactions on Asian and LowResource Language Information Processing, vol. 8, no. 4, pp. 14:114:22, 2009.

\section{AUTHORS’ PROFILE}

Fahad Alliheibi is a Full Professor of Arabic Language and Linguistics in the Department of Arabic Language, College of Arts, King Abdulaziz University (KSA). Prof. Alliheibi received his PhD degree in Linguistics in 1999 from Durham University, UK. His research interests include Arabic Linguistics, Pragmatics, Text Linguistics, and Translation.

ORCID: 0000-0002-2233-5165
Abdulfattah Omar is an Associate Professor of English Language and Linguistics in the Department of English, College of Science \& Humanities, Prince Sattam Bin Abdulaziz University (KSA). Also, he is a standing lecturer of English Language and Linguistics in the Department of English, Faculty of Arts, Port Said University, Egypt. Dr Omar received his PhD degree in computational linguistics in 2010 from Newcastle University, UK. His research interests include computational linguistics, digital humanities, discourse analysis, and translation studies.

\section{ORCID: 0000-0002-3618-1750}

Nasser Al-Horais is a Full Professor of Arabic Language and Linguistics in the Department of Arabic Language and its Arts, College of Arabic Language \& Social Studies, Qassim University (KSA). Prof. Al-Horais received his $\mathrm{PhD}$ degree in Linguistics in 2009 from Newcastle University, UK. His research interests include Arabic Syntax, Generative Linguistics (Minimalist Program), Discourse Analysis, and Comparative Syntax.

ORCID: 0000-0002-2511-9791

P.O.Box 6611, Buraidah 51425, Saudi Arabia

APPENDIX No. 1: SELECTED NEWSPAPER ARTICLES AND CODES

\begin{tabular}{|c|c|c|c|c|}
\hline Title & Code & Category & Newspaper & Country \\
\hline تحريز الأسعار ... وقود الحر ائق & \multirow{3}{*}{01} & \multirow{3}{*}{ Business } & \multirow{3}{*}{ Assabah } & \multirow{3}{*}{ Morocco } \\
\hline tahrir al'asear ... waqud alharayiq & & & & \\
\hline Price liberalization...Adding fuel to the fire & & & & \\
\hline معتز صدقى: صناعة السباحة على مستوى العالم 》هشةهي & \multirow{3}{*}{02} & \multirow{3}{*}{ Business } & \multirow{3}{*}{ Al-Ahram } & \multirow{3}{*}{ Egypt } \\
\hline muetaz sdqy: sinaeat alsiyahat ealaa mustawaa alealam 'hashah' & & & & \\
\hline Moataz Sidqi: The global tourism industry is 'fragile' & & & & \\
\hline تسهيلات جمركية للسيار ات الكهربائية المستعملة & \multirow{3}{*}{03} & \multirow{3}{*}{ Business } & \multirow{3}{*}{ Al-Ahram } & \multirow{3}{*}{ Egypt } \\
\hline tashilat jumrukiat lilsayarat alkahrabayiyat almustaemala & & & & \\
\hline Egypt approves new customs tax breaks for used electric cars & & & & \\
\hline تدهور تاريخي لليرة السورية أمام الدولار & \multirow{3}{*}{04} & \multirow{3}{*}{ Business } & \multirow{3}{*}{ Al-Watan } & \multirow{3}{*}{ Kuwait } \\
\hline tadahwur tarikhi liliarat alsuwriat 'amam alduwlar & & & & \\
\hline Historical deterioration of the Syrian pound against the dollar & & & & \\
\hline انتاج" تناقش التحديات و الفرص لتنمية الصادر ات الأردنية لتكنولوجيا المعلومات" & \multirow{3}{*}{05} & \multirow{3}{*}{ Business } & \multirow{3}{*}{ Alrai } & \multirow{3}{*}{ Jordan } \\
\hline $\begin{array}{l}\text { "Intaj" tunaqash altahadiyat walfuras litanmiat alssadirat al'urduniyat litiknulujia } \\
\text { almaelumat }\end{array}$ & & & & \\
\hline $\begin{array}{l}\text { "Intaj" discusses the challenges and opportunities for developing Jordanian exports of } \\
\text { information technology }\end{array}$ & & & & \\
\hline المنتدى الاقتصادي الأردنى يطالب بإعادة النظر في مفوم القطاع العام و أهدافه وطريقة المساءلة & \multirow{3}{*}{06} & \multirow{3}{*}{ Business } & \multirow{3}{*}{ Alrai } & \multirow{3}{*}{ Jordan } \\
\hline $\begin{array}{l}\text { almuntadaa alaiqtisadiu al'urduniyu yutalib bi'iieadat alnazar fi mafhum alqitae aleami } \\
\text { wa'ahdafah watariqat almusa'ala }\end{array}$ & & & & \\
\hline $\begin{array}{l}\text { The Jordanian Economic Forum calls for a review of the concept of the public sector, } \\
\text { its objectives, and the methods of accountability }\end{array}$ & & & & \\
\hline أير أسيا: نعمل على إطلاق خذمة التاكسي الطائر & \multirow{3}{*}{07} & \multirow{3}{*}{ Business } & \multirow{3}{*}{ Al-Itihad } & \multirow{3}{*}{ Emirates } \\
\hline 'ayr 'asya: naemal ealaa 'iitlaq khidmat alttakisii alttayir & & & & \\
\hline AirAsia: We are working on launching the Flying Taxi service & & & & \\
\hline وز ارة التجارة السعودية: منح 100 ألف سجل تجاري لسيدات خلال 2020 & \multirow{3}{*}{08} & \multirow{3}{*}{ Business } & \multirow{3}{*}{ Al-Bayan } & \multirow{3}{*}{ Emirates } \\
\hline wizarat altijarat alsaeudiati: manh 100 'alf sajal tijariun lasaydat khilal 2020 & & & & \\
\hline Saudi Arabia issued over 100,000 commercial registrations for women in 2020 & & & & \\
\hline إدانة ساركوزي بتهم الفساد & \multirow{2}{*}{09} & Politics & Assabah & Morocco \\
\hline 'iidanat sarkwzy bituham alfasad & & & & \\
\hline
\end{tabular}




\begin{tabular}{|c|c|c|c|c|}
\hline Former French President Nicolas Sarkozy Found Guilty Of Corruption & & & & \\
\hline 》النقد الدوليه يدعو الحكومات للنظر بعين الاعتبار للنساء عند إعداد ميز انياتها & \multirow{3}{*}{10} & \multirow{3}{*}{ Politics } & \multirow{3}{*}{ Al-Ahram } & \multirow{3}{*}{ Egypt } \\
\hline $\begin{array}{l}\text { "alnaqd alduwly” yadeu alhukumat lilnazar bieayn alaietibar lilnisa' eind 'iiedad } \\
\text { mizaniatiha }\end{array}$ & & & & \\
\hline $\begin{array}{r}\text { The International Monetary Fund calls on governments to consider women when } \\
\text { preparing their budgets }\end{array}$ & & & & \\
\hline وزير الإعلام اليمني: ميليشيا الحوثي تو اصل المر او غة و التناعب بملف ناقلة النفط صافر & \multirow{3}{*}{11} & \multirow{3}{*}{ Politics } & \multirow{3}{*}{ Al-Ahram } & \multirow{3}{*}{ Egypt } \\
\hline $\begin{array}{l}\text { wazir al'iielam alyamani: milishia alhawthayi tuasil almurawaghat waltalaeub bimalf } \\
\text { naqilat alnaft safir }\end{array}$ & & & & \\
\hline $\begin{array}{l}\text { Houthis spreading misleading information regarding Safer tanker: The Yemeni } \\
\text { Information Minister }\end{array}$ & & & & \\
\hline زيارة بابا الفاتيكان للعر اق استدعاء لقيم العيش المشترك & \multirow{3}{*}{12} & \multirow{3}{*}{ Politics } & \multirow{3}{*}{ Al-Ahram } & \multirow{3}{*}{ Egypt } \\
\hline ziarat $\mathrm{PaPa}$ alvatikan lileiraq aistidea' liqim aleaysh almushtara & & & & \\
\hline Pope's visit to Iraq sends message of coexistence & & & & \\
\hline قلق سعودي من تنامي وتيرة خطاب الكر اهية ضد المسلمين & \multirow{3}{*}{13} & \multirow{3}{*}{ Politics } & \multirow{3}{*}{ Al-Jazeera } & \multirow{3}{*}{ Saudi Arabia } \\
\hline qalaq saeudiun min tanami watirat khitab alkirahiat dida almuslimin & & & & \\
\hline$\underline{\text { Saudi concern for the growing hate speech against Muslims }}$ & & & & \\
\hline الرياض تطالب مجلس الأمن بمحاسبة الحوثيين على إرهابهر & \multirow{3}{*}{14} & \multirow{3}{*}{ Politics } & \multirow{3}{*}{ Asharq Al-Awsat } & \multirow{3}{*}{ Saudi Arabia } \\
\hline alriyad tutalib majlis al'amn bimuhasabat alhuthiayn ealaa 'iirhabihim & & & & \\
\hline Saudi Arabia calls on UN to hold Houthis accountable for terror attacks & & & & \\
\hline إر ادة الشعب و المر اهقة السياسية & \multirow{3}{*}{15} & \multirow{3}{*}{ Politics } & \multirow{3}{*}{ Al-Watan } & \multirow{3}{*}{ Kuwait } \\
\hline 'iiradat alshaeb walmurahaqat alsiyasia & & & & \\
\hline The will of the people and the immaturity of the politicians & & & & \\
\hline آلاف الجز ائريين يتظاهرون في الاسبوع الثانى من استئناف مسير ات الحر الك & \multirow{3}{*}{16} & \multirow{3}{*}{ Politics } & \multirow{3}{*}{ Alrai } & \\
\hline alaf aljazayiriiyn yatazaharun fi al'usbue alththani min aistinaf masirat alhirak & & & & Jordan \\
\hline Thousands of Algerians demonstrate in the second week of Hirak's recovery & & & & \\
\hline كاف” تطلق عصبة الأبطال النسوية"، & & & & \\
\hline "kaf" tutliq eusbat al'abtal alnaswia & 17 & Sports & Assabah & Morocco \\
\hline CAF launches Women's Champions League & & & & \\
\hline كلوب: الهزيمة أمام تشيلسى ضربة قوية & & & & \\
\hline klwb: alhazimat 'amam tshylsy darbatan qawia & 18 & Sports & Asharq Al-Awsat & Saudi Arabia \\
\hline Jurgen Klopp admitted Liverpool's defeat against Chelsea was a massive blow & & & & \\
\hline الإفلاس يضرب 16 نادياً في الدوري الصيني & & & & \\
\hline al'iiflas yadrib 16 nadyaan fi aldawrii alsiynii & 19 & Sports & Al-Jazeera & Saudi Arabia \\
\hline Bankruptcy hits 16 clubs in the Chinese Football League & & & & \\
\hline الأسطورة بوفون يكثف مو عد اعتز اله & & & & \\
\hline al'usturat bufun yakshif maweid aietizalah & 20 & Sports & Al-Watan & Kuwait \\
\hline Buffon reveals when he wants to retire & & & & \\
\hline "دربي" مانثستر في الو اجهة... وليفربول لاستعادة "سمعته & & & & \\
\hline "drabi" manshistar fi alwajihta... walifarbul liaistieada "smieatih & 21 & Sports & Annahar & Lebanon \\
\hline "Derby" Manchester in the forefront ... and Liverpool to restore "its reputation & & & & \\
\hline الكرة المصرية... مو اهب ارأتلفها الهوى & ר? & Snortc & Al Rau & Fminato \\
\hline alkurat almisriata.. mawahib iatalifaha alhuaa & 22 & sports & АI-Duуап & 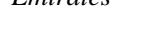 \\
\hline
\end{tabular}




\begin{tabular}{|c|c|c|c|c|}
\hline The Egyptian Football: Wasted football talents & & & & \\
\hline برشلونة يترقب رئيسه الجديد وسط جائحة كورونا و عاصفة من الأزمات & \multirow{3}{*}{23} & \multirow{3}{*}{ Sports } & \multirow{3}{*}{ Al-Bayan } & \multirow{3}{*}{ Emirates } \\
\hline $\begin{array}{r}\text { barshilunat yataraqab rayiysih aljadid wasat jayihat kwrwna waeasifatan min } \\
\text { al'azamat }\end{array}$ & & & & \\
\hline Barcelona elects new president amid Pandemic COVID-19 and a storm of crises & & & & \\
\hline إبر اهيموفيتش.. الالعودة وشيكةه إلى منتخب السويد & 24 & Sports & \multirow{3}{*}{ Al-Itihad } & \multirow{3}{*}{ Emirates } \\
\hline Iibrahymwfytsh: aleawdat wshy 'iilaa muntakhab alsuwid & & & & \\
\hline Ibrahimovic's return to the Swedish national team is imminent & & & & \\
\hline در اسة طبية: توفير الثقة و الدعم للمر اهقين يساعدهم في التغلب على الاكتئاب & 25 & ETF & \multirow{3}{*}{ Al-Ahram } & \multirow{3}{*}{ Egypt } \\
\hline $\begin{array}{l}\text { dirasat tbyt: tawfir althiqat waldem lilmurahiqin yusaeiduhum fi altaghalub ealaa } \\
\text { alaiktiab }\end{array}$ & & & & \\
\hline $\begin{array}{l}\text { Clinical Study: Providing teens with confidence and support helps them overcome } \\
\text { depression }\end{array}$ & & & & \\
\hline 》الجارديانه تختار مسجد السلطان برقوق كأحد أفضل 10 زيار ات افتر اضية في العالح & 26 & ETF & \multirow{3}{*}{ Al-Ahram } & \multirow{3}{*}{ Egypt } \\
\hline "aljardyan” takhtar masjid alsultan biruquq kahd 'afdal 10 ziarat aiftiradiatan fi alealam & & & & \\
\hline $\begin{array}{l}\text { The Guardian chose the Mosque-Madrassa of Sultan Barquq among the } 10 \text { virtual } \\
\text { tours of spectacular buildings around the world }\end{array}$ & & & & \\
\hline 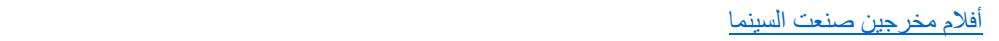 & 27 & ETF & \multirow{3}{*}{ Asharq Al-Awsat } & \multirow{3}{*}{ Saudi Arabia } \\
\hline 'aflam mukhrijin sunieat alsiynama & & & & \\
\hline Debut Films of Famous Directors & & & & \\
\hline 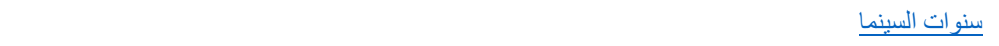 & 28 & ETF & \multirow{3}{*}{ Asharq Al-Awsat } & \multirow{3}{*}{ Saudi Arabia } \\
\hline sanawat alsiynama & & & & \\
\hline Cinema years & & & & \\
\hline السينما بعيون أفلاطون & 29 & ETF & \multirow{3}{*}{ Al-Jazeera } & \multirow{3}{*}{ Saudi Arabia } \\
\hline alsiynama bieuyun 'aflatun & & & & \\
\hline Cinema through Plato's Eyes & & & & \\
\hline .تحول الصحف الورقية إلى إلكترونية يسير وتحتاج إلى الدع. & 30 & ETF & \multirow{3}{*}{ Al-Jazeera } & \multirow{3}{*}{ Saudi Arabia } \\
\hline tahul alsuhuf alwarqiat 'iilaa 'iiliktruniat yasir watahtaj 'iilaa alduem. & & & & \\
\hline Converting traditional newspapers to electronic is easy and needs support & & & & \\
\hline وثائقي جديد يكثف الوجه القبيح لللخر ج الأمريكي وودي ألن & 31 & ETF & \multirow{3}{*}{ Al-Watan } & \multirow{3}{*}{ Kuwait } \\
\hline wathayiqiin jadid yakshif alwajh alqubih lilmukhrij al'amrikii wawdi 'alan & & & & \\
\hline A new documentary reveals the ugly face of American filmmaker Woody Allen & & & & \\
\hline الحب المنبادل ينمي ذكاء الأطفال & 32 & ETF & Assabah & \multirow{3}{*}{ Morocco } \\
\hline alhabu almutabadal yanmi dhaka' al'atfal & & & & \\
\hline Mutual love develops children's intelligence & & & & \\
\hline علماء يبحثثون عن آثار حياة على بعد 26 سنة ضوئية فقط & \multirow{3}{*}{33} & \multirow{3}{*}{$\mathrm{S} \& \mathrm{~T}$} & \multirow{3}{*}{ Al-Itihad } & \multirow{3}{*}{ Emirates } \\
\hline eulama' yabhathun ean athar hayat ealaa bued 26 sanatan dawyiyatan faqa & & & & \\
\hline Scientists find Earth-like planet with an atmosphere 26 light years away & & & & \\
\hline تويتز " يتح ميزة جديدة كان يطالب بها المستخدمون" & \multirow{3}{*}{34} & \multirow{3}{*}{$\mathrm{S} \& \mathrm{~T}$} & \multirow{3}{*}{ Al-Bayan } & \\
\hline "Twitter" yutih myzt jadidatan kan yutalib biha almustakhdimun & & & & Emirates \\
\hline "Twitter" provides a new feature that was demanded by users & & & & \\
\hline و واتساب تطلق المكالمات الصوتية و المرئية لتطبيق الويب قريبياً & 35 & $\mathrm{~S} \& \mathrm{~T}$ & Annahar & Lebanon \\
\hline
\end{tabular}


(IJACSA) International Journal of Advanced Computer Science and Applications,

Vol. 12, No. 5, 2021

\begin{tabular}{|c|c|c|c|c|}
\hline Whatsapp tutliq almukalamat alsawtiat walmaryiyat litatbiq alwayb qrybaan & & & & \\
\hline WhatsApp is launching audio and video calls for the web app soon & & & & \\
\hline الثنييهة بفيديو ات "تيك توك"Fast Laughsنتفليكس تطلق & \multirow{3}{*}{36} & \multirow{3}{*}{$\mathrm{S} \& \mathrm{~T}$} & \multirow{3}{*}{ Annahar } & \multirow{3}{*}{ Lebanon } \\
\hline natiflikis tutliq FAST LAUGHS alshbyht bfydywat "tyk twk" & & & & \\
\hline Netflix launches short-form video feature similar to TikTok & & & & \\
\hline "بايت دانس" تطور تطبيقًا شبيهاً بـ "كلوب هاوس" & 37 & $\mathrm{~S} \& \mathrm{~T}$ & \multirow{3}{*}{ Annahar } & \multirow{3}{*}{ Lebanon } \\
\hline "byte dance" tatawur ttbyqana shbyhaan b "klub haws" & & & & \\
\hline Byte Dance develops a clubhouse-like app & & & & \\
\hline أداة ذكية تدمج بالهاتف لقياس الحرارة & 38 & $\mathrm{~S} \& \mathrm{~T}$ & \multirow{3}{*}{ Al-Jazeera } & \multirow{3}{*}{ Saudi Arabia } \\
\hline 'adat dhakiat tadmaj bialhatif liqias alharara & & & & \\
\hline A smart tool integrated into the phone to measure the temperature & & & & \\
\hline هياكل روبوتية خارجية تدعم قوة العمل البشرية & 39 & $\mathrm{~S} \& \mathrm{~T}$ & \multirow{3}{*}{ Asharq Al-Awsat } & \multirow{3}{*}{ Saudi Arabia } \\
\hline hiakl rubutiat kharijiat tadeam quat aleamal albasharia & & & & \\
\hline Robotic exoskeletons support the human workforce & & & & \\
\hline حسام مو افى يكثف عن سبب دقات القلب العالية & 40 & $\mathrm{~S} \& \mathrm{~T}$ & \multirow{3}{*}{ Al-Ahram } & \multirow{3}{*}{ Egypt } \\
\hline husam mawafi yukshaf ean sbb daqqat alqalb alealia & & & & \\
\hline Hussam Mowafi reveals the cause of the high heart rate & & & & \\
\hline
\end{tabular}

